\title{
Late Neogene-Quaternary radiolarian biostratigraphy: a brief review
}

\author{
SIMON K. HASLETT \\ Quaternary Research Unit, Department of Geography, School of Science and the Environment, Bath Spa University College, Newton Park, \\ Bath, BA2 9BN, UK (e-mail: s.haslett@bathspa.ac.uk).
}

\begin{abstract}
Since the 1950s, it has become apparent that Radiolaria have significant biostratigraphical potential throughout Phanerozoic time, including the Late Neogene and Quaternary. Radiolarian biozonation schemes for this period have been developed, including a Standard Tropical Zonation, which illustrates the pan-oceanic application of radiolarian biostratigraphy to Pliocene-Quaternary sediments. The biostratigraphical resolution obtainable using Radiolaria is equivalent to other microfossil groups, such as planktonic foraminifera. The recognition of abundance events of Cycladophora davisiana, and of some other species, are an alternative radiolarian dating technique for the Pliocene-Quaternary, akin to dating sediment using oxygen stable isotope $\left(\delta^{18} \mathrm{O}\right)$ records and with similar resolution. A number of studies have used astronomical timescales, derived from orbitally tuning $\delta^{18} \mathrm{O}$ and gamma ray attenuation porosity evaluator (GRAPE) records, to provide ages for radiolarian biodatums. This approach should be adopted as a more accurate alternative to palaeomagnetic chronologies with their inherent flaws. This commentary concludes that Radiolaria are important microfossils and, as a group, continue to offer significant potential as a biostratigraphical tool in future studies of the marine Pliocene-Quaternary. J. Micropalaeontol. 23(1): 39-47, May 2004.
\end{abstract}

\section{INTRODUCTION}

Polycystine Radiolaria are planktonic marine sarcodine Protozoa that secrete a siliceous opaline test. The Superorder Polycystina is divided into two Orders of Radiolaria, the Spumellaria (skeleton in the form of a sphere, or derived from a sphere, e.g. ellipsoidal, discoidal, lenticular, spiral) and the Nassellaria (skeleton bipolar and usually bilaterally symmetrical). Although Cenozoic Radiolaria can be studied using both reflected light and scanning electron microscopy, traditionally they have been mounted in Canada balsam and viewed in transmitted light. This allows for examination of internal spicules and skeletal structure, features that are important for identification (Kling, 1978; Brasier, 1980; Anderson, 1983; Casey, 1993; Haslett, 1993; De Wever et al., 1994). The purpose of this paper is to comment on the use of Radiolaria in dating deep-sea sediments and to complement a recent review of radiolarian palaeoenvironmental applications (Haslett, 2002). This paper has been stimulated by the lack of a review dedicated to Quaternary radiolarian biostratigraphy which has contributed to a number of misconceptions, such as the statement by Lowe \& Walker (1997, p. 218) that information on the Quaternary stratigraphy of radiolarians is currently limited'.

\section{BRIEF HISTORY OF RADIOLARIAN TAXONOMY}

Radiolaria were first described by F. J. F. Meyen in 1834, but it was the work of the famous microscopists, C. G. Ehrenberg and Ernst Haeckel, that established a taxonomic framework for radiolarian classification. The system proposed by Haeckel in the reports of the Challenger voyages in 1887 was primarily based on the geometry of the radiolarian test and, even at the time, Haeckel himself recognized its artificiality. Radiolaria have been found to possess a long geological record, extending back to the Cambrian (c. 500 million years ago). A consequence of the artificial Haeckelian classification was that early workers of fossil Radiolaria encountered similar test geometries to the living and Holocene specimens described by Haeckel (1887).
This gave the impression that Radiolaria were an evolutionary stable group of organisms that had remained unchanged since their origin in the Early Palaeozoic and, therefore, were of little biostratigraphical value. It was not until the work of W. R. Riedel in the 1950s and 1960s that a more natural classification began to emerge (Riedel, 1953, 1957, 1959, 1967). Riedel and his colleagues concentrated on tracing phylogenetic lineages through time, finding that many species have quite short geological ranges, making them ideal for biostratigraphy (Sanfilippo \& Riedel, 1970, 1980, 1982, 1992; Riedel \& Sanfilippo, 1978, 1986; Westberg \& Riedel, 1978).

\section{RADIOLARIAN BIODATUMS AND BIOZONATIONS}

Radiolarian evolutionary events are typically used as biodatums, such as the inception or extinction of species, although some acme events have been proposed. Biodatums are generally referred to as First Appearance Datums (FADs) and Last Appearance Datums (LADs), although other denotations are used, such as morphotypic base and top (Bm and Tm). Some biodatums are used to define biozones (intervals of time defined by biological markers) according to standard international procedure (Hedberg, 1976). A biodatum selected for this purpose ideally has a widespread geographical occurrence, with the event occurring synchronously from place to place. Radiolarian biozones are commonly erected as Range Chronozones or Interval Chronozones. A Range Chronozone is defined by the total stratigraphic range of an individual species, from its FAD to its LAD, and is usually named after the nominate species. An Interval Chronozone is defined using biodatums from different species, for example, from the LAD of one species to the FAD of another, and may be named after one of the species, or by some other species which may be common within the time interval represented by the biozone.

The first radiolarian biozonal scheme for the Quaternary of the equatorial Pacific and Indian Oceans was presented in Nigrini (1971) in which she erected four biozones (Fig. 1). This 


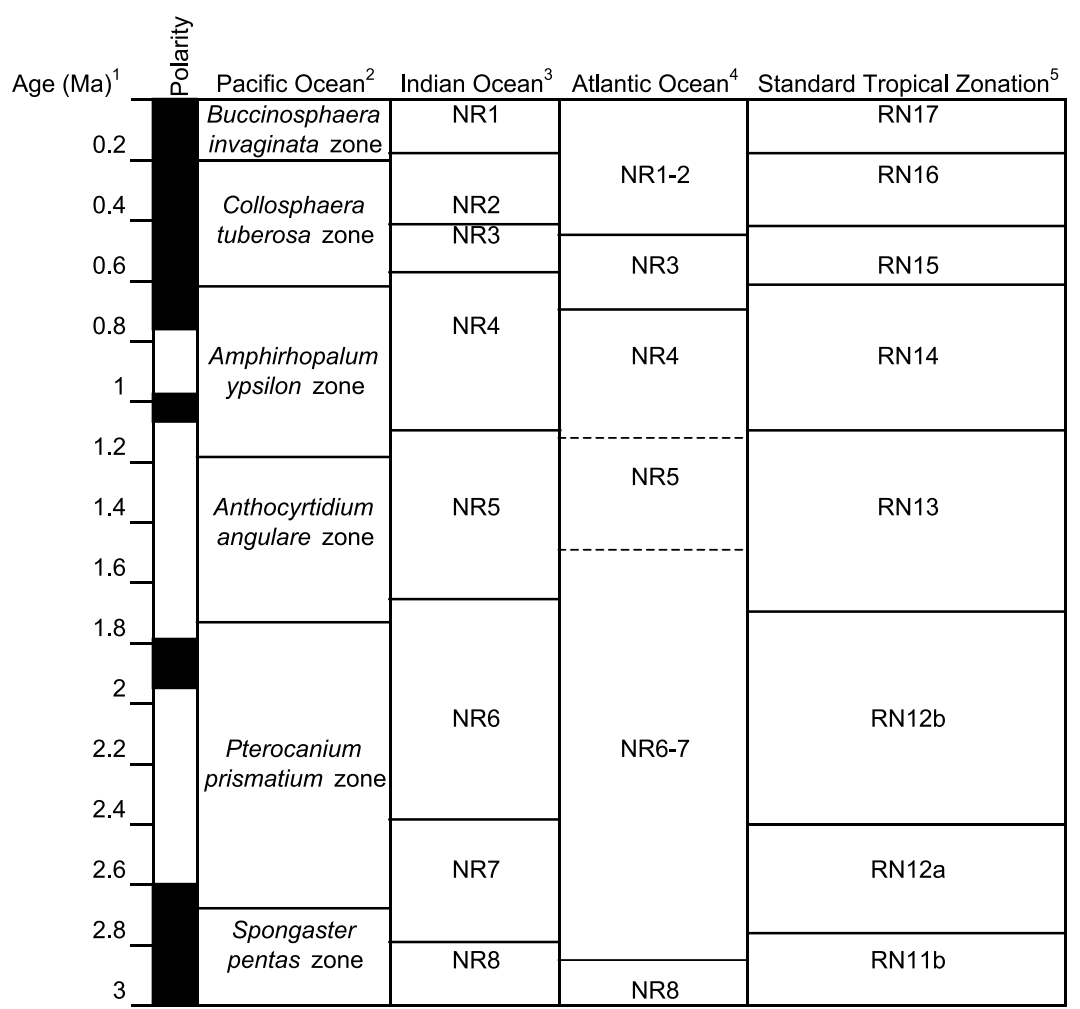

Fig. 1. Radiolarian biostraigraphic zonal schemes for the Pacific, Indian, and Atlantic Oceans (see Tables 1 and 3 for explanation of zone abbreviations). References: ${ }^{1}$ Shackleton et al. (1990, 1995); ${ }^{2}$ Nigrini (1971), Sanfilippo et al. (1985), Moore et al. (1993); ${ }^{3}$ Johnson et al. (1989); ${ }^{4}$ Haslett (1994); ${ }^{5}$ Sanfilippo \& Nigrini (1998). Dashed line indicates tentative boundary position.

work provided a means of relatively dating tropical Quaternary sediments using Radiolaria. Absolute ages for these biodatums were later provided in Johnson \& Knoll (1975). The stratigraphic resolution obtainable using Nigrini's (1971) scheme, with only four biozones spanning the entire Quaternary, is inevitably coarse. Yet, despite this, the scheme has been widely used, mainly because it is easy to apply, and has been incorporated into a 'standard' Cenozoic low-latitude radiolarian biozonation (e.g. Riedel \& Sanfilippo, 1978; Sanfilippo et al., 1985). This is not for the lack of alternative schemes, as Goll (1980), for example, erected a more refined biozonation for the tropical Pacific. Also, other schemes have been erected for other geographical regions, such as the North Pacific (Hays, 1970; Kling, 1973; Foreman, 1975), North Atlantic (see review by Haslett, 1995), northeast Atlantic (Björklund, 1976; Goll \& Björklund, 1980) and Antarctica (Hays, 1965, 1967; Hays \& Opdyke, 1967; Chen, 1975).

In the late 1980 s a concerted attempt was made to provide a new higher resolution Pliocene-Pleistocene radiolarian biozonation. This was initiated by an extensive appraisal of the timing of known Neogene radiolarian biodatums in palaeomagnetically and biostratigraphically dated cores from the equatorial Indian and Pacific Oceans (Johnson \& Nigrini, 1985). This study indicated that a number of biodatums previously used as biozonal boundary markers were diachronous and unsuitable for inter-oceanic biostratigraphy (see also Spencer-Cervato et al., 1993). These results contributed further to the lack of suitable radiolarian species available for Pliocene-Pleistocene biostratigraphy. Perhaps, in response to this situation, taxo- nomic studies were undertaken on two potentially useful genera of Radiolaria, Pterocorys (Caulet \& Nigrini, 1988) and Anthocyrtidium (Nigrini \& Caulet, 1988), which provided a number of new biodatums based on Indian and Pacific Ocean material, again from palaeomagnetically and biostratigraphically dated cores. Subsequentally, Johnson et al. (1989) erected a new palaeomagnetically calibrated Pliocene-Pleistocene radiolarian biozonation for the tropical Indian Ocean, later refined by Caulet et al. (1993) (Fig. 1; Table 1). Johnson et al. (1989) recognized 33 radiolarian biodatums and erected 11 biozones for the Pliocene-Pleistocene, nearly doubling the number of biozones reported earlier for the same interval by Sanfilippo et al. (1985). This increase in biozones put Radiolaria on a par with other microfossil biozonations, such as planktonic Foraminifera (Bolli \& Saunders, 1985) and calcareous nannofossils (Martini, 1971), but exceeding the resolution obtainable through diatoms (Barron, 1985).

All of this work referred to the Indian and Pacific oceans, and there was little information concerning the biostratigraphic application of these species in the Atlantic Ocean. Haslett (1994) published an account of Pliocene-Pleistocene radiolarian biostratigraphy at DSDP Site 609 in the North Atlantic (Fig. 1) and demonstrated that elements of Johnson et al.'s (1989) biozonation could be applied in the Atlantic Ocean. This suggests that this scheme offered the potential to become a standard Pliocene-Pleistocene biozonation, enabling correlation throughout the world's tropical to mid-latitude oceans. This is hampered somewhat, however, by the apparent diachroneity of some biodatums between the Indian and Atlantic oceans (Table 2). 


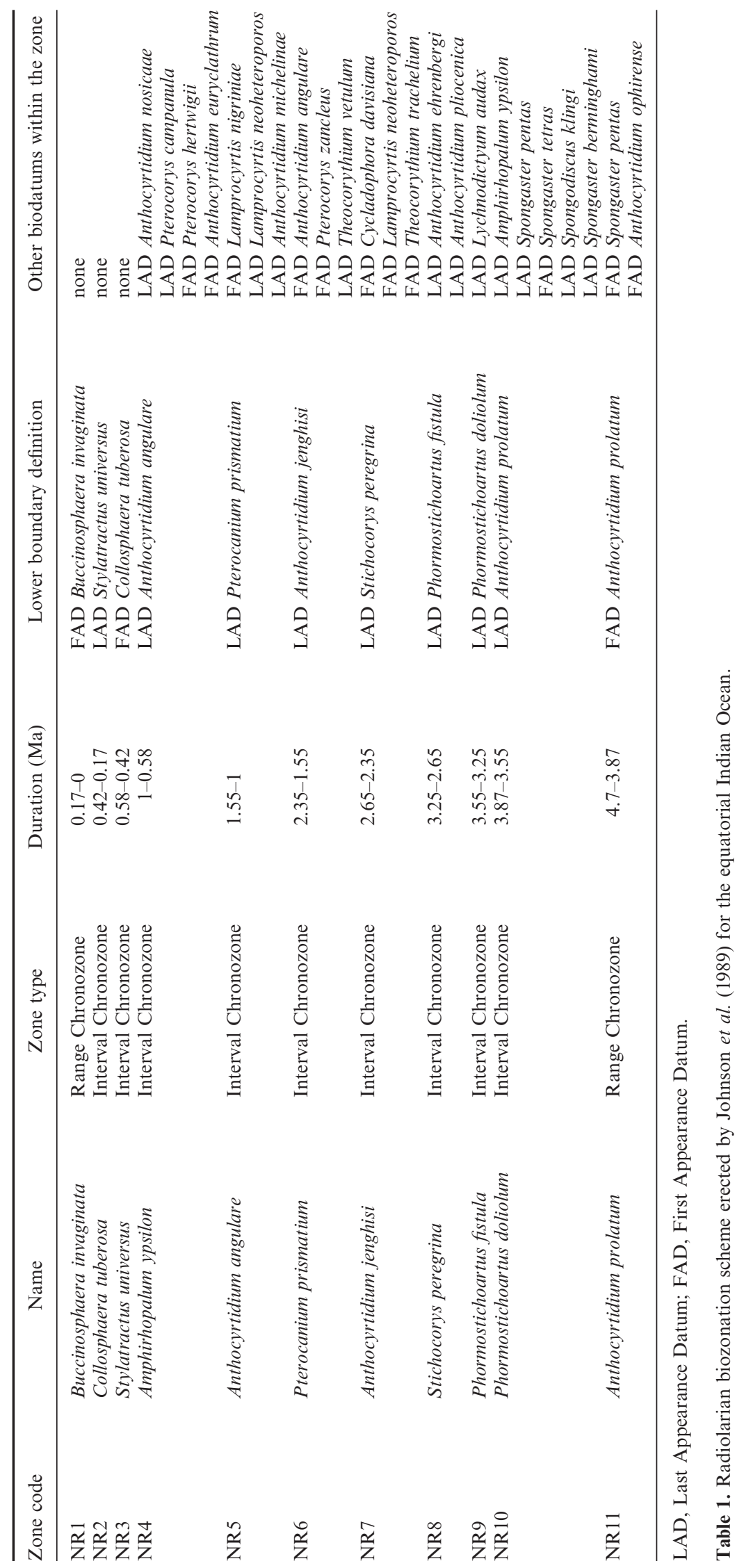




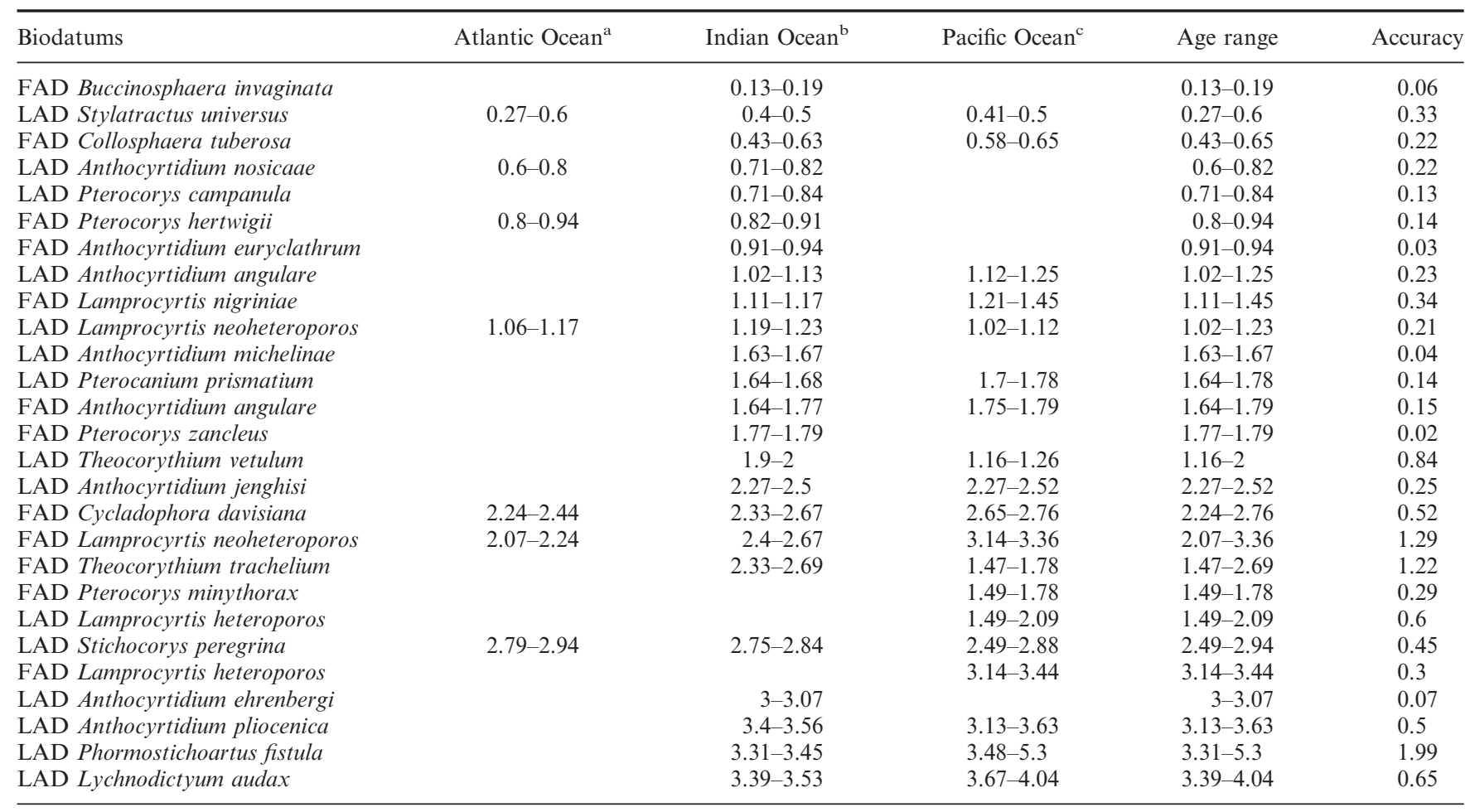

a after Haslett (1994) and Westberg-Smith et al. (1986)

bafter Johnson et al. (1989) and Haslett et al. (1995)

${ }^{\mathrm{c}}$ Moore et al. (1993) and Moore (1995)

Table 2. Radiolarian biodatum ages in the Atlantic, Indian and Pacific oceans. Ages for Atlantic and Indian Ocean biodatums are recalculated here using astronomically derived ages for palaeomagnetic reversals (Shackleton et al., 1990, 1995).

Recognition of five Pleistocene radiolarian zones (NR1-NR5) has been made in the South China Sea (Wang \& Abelmann, 1999), further extending the wide application of this radiolarian biozonation scheme.

The absolute ages for these biodatums were calculated in all cases cited above through interpolation between dated palaeomagnetic reversals using the time-scale of Berggren et al. (1985a, b). Johnson et al. (1989) suggest that the precision of some biodatums is less than $100 \mathrm{ka}$; however, little consideration is given to possible variations in sedimentation between reversals. Ruddiman et al. (1986) and Shackleton et al. (1990, 1995) provide an alternative method of dating sedimentary cores by tuning $\delta^{18} \mathrm{O}$ and gamma ray attenuation porosity evaluator (GRAPE) density records to the periodicity of astronomical cycles: $400 \mathrm{ka}$ and $100 \mathrm{ka}$ eccentricity cycles, $41 \mathrm{ka}$ obliquity cycles and 23-19 ka precessional cycles. This method commonly allows for samples to be dated to within c. $20 \mathrm{ka}$ (i.e. interval between adjacent precessional excursions) and enables very high precision ages to be applied to biodatums. Moore et al. (1993) and Moore (1995) exploit astronomical time-scales constructed for ODP Leg 138 cores from the eastern equatorial Pacific to derive ages for the assessment of diachroneity of NeogeneQuaternary radiolarian biodatums in the region (Table 2). They categorized all events occurring throughout the region within $150 \mathrm{ka}$ as synchronous, and six of the eleven Quaternary (c. 0-2 Ma) biodatums in the eastern equatorial Pacific met this criteria. Of the diachronous events, only one was significantly greater than $300 \mathrm{ka}$. This study is important for the accuracy of the astronomically tuned ages applied to the radiolarian biodatums, which does not involve the same degree of interpolation as palaeomagnetic time-scales.

Extending this approach into the Indian Ocean, Haslett et al. (1995) investigated a Pliocene-Early Pleistocene section from ODP Site 709 and identified ten radiolarian biodatums. Oxygen isotope stratigraphy is available for part of the section (Shackleton \& Hall, 1990), which was astronomically tuned by correlation with ODP Site 677 (Shackleton et al., 1990; see also Funnell et al., 1996), allowing dates to be assigned to six biodatums (Table 2). Only one of the biodatums identified in ODP Site 709 (LAD Anthocyrtidium jenghisi) appears to be synchronous with the eastern equatorial Pacific, as defined by Moore et al. (1993). To date, no attempt has been made to extend this approach of dating radiolarian biodatums through the entire Quaternary of the Indian Ocean, or at all in the Atlantic Ocean. These are pressing objectives that are required for a fully integrated low-latitude radiolarian biozonation of the world's oceans.

Recently, Sanfilippo \& Nigrini (1998) have offered a revised biozonal nomenclature for the Cenozoic, which provides a Standard Tropical Zonation based on Radiolaria with the introduction of new code numbers (Fig. 1 and Table 3). In terms of the Pliocene-Pleistocene part of this zonation the main departure from Johnson et al. (1989) occurs in the Pliocene where their zones NR6 and NR7 are replaced with a single zone 


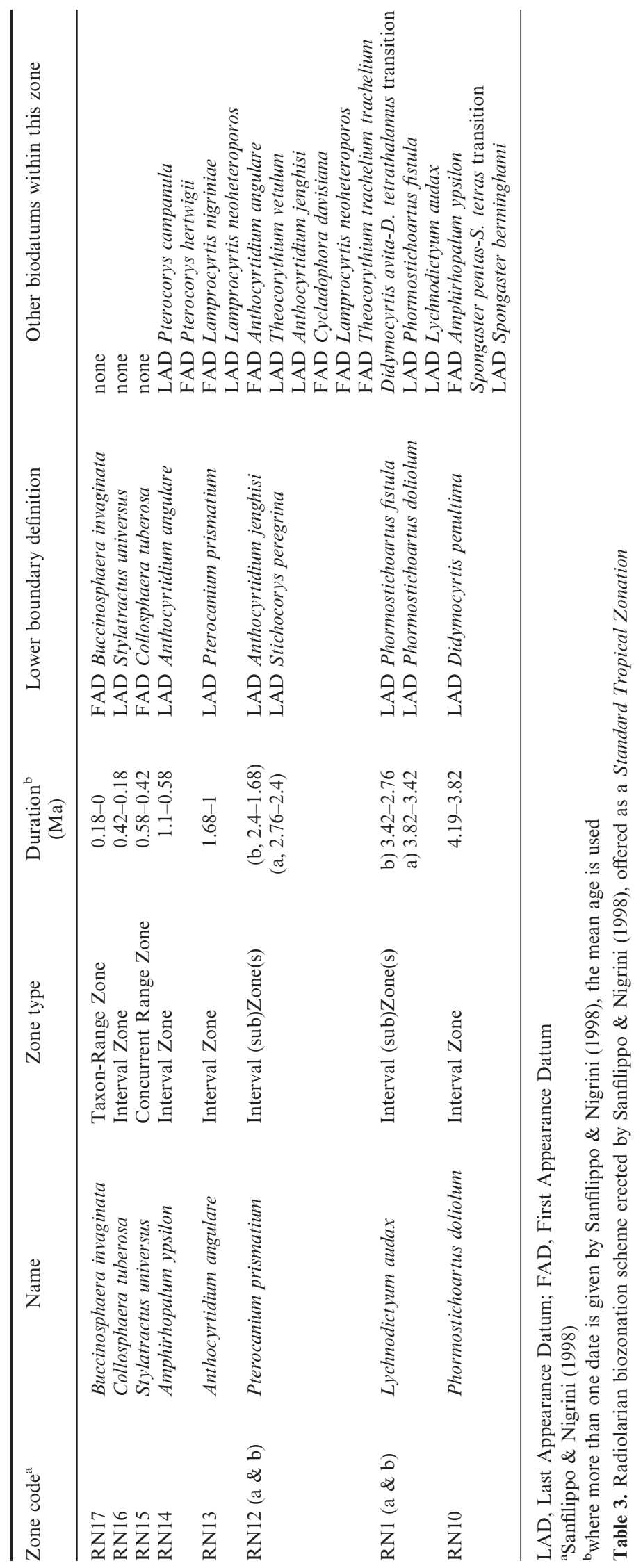


S. K. Haslett
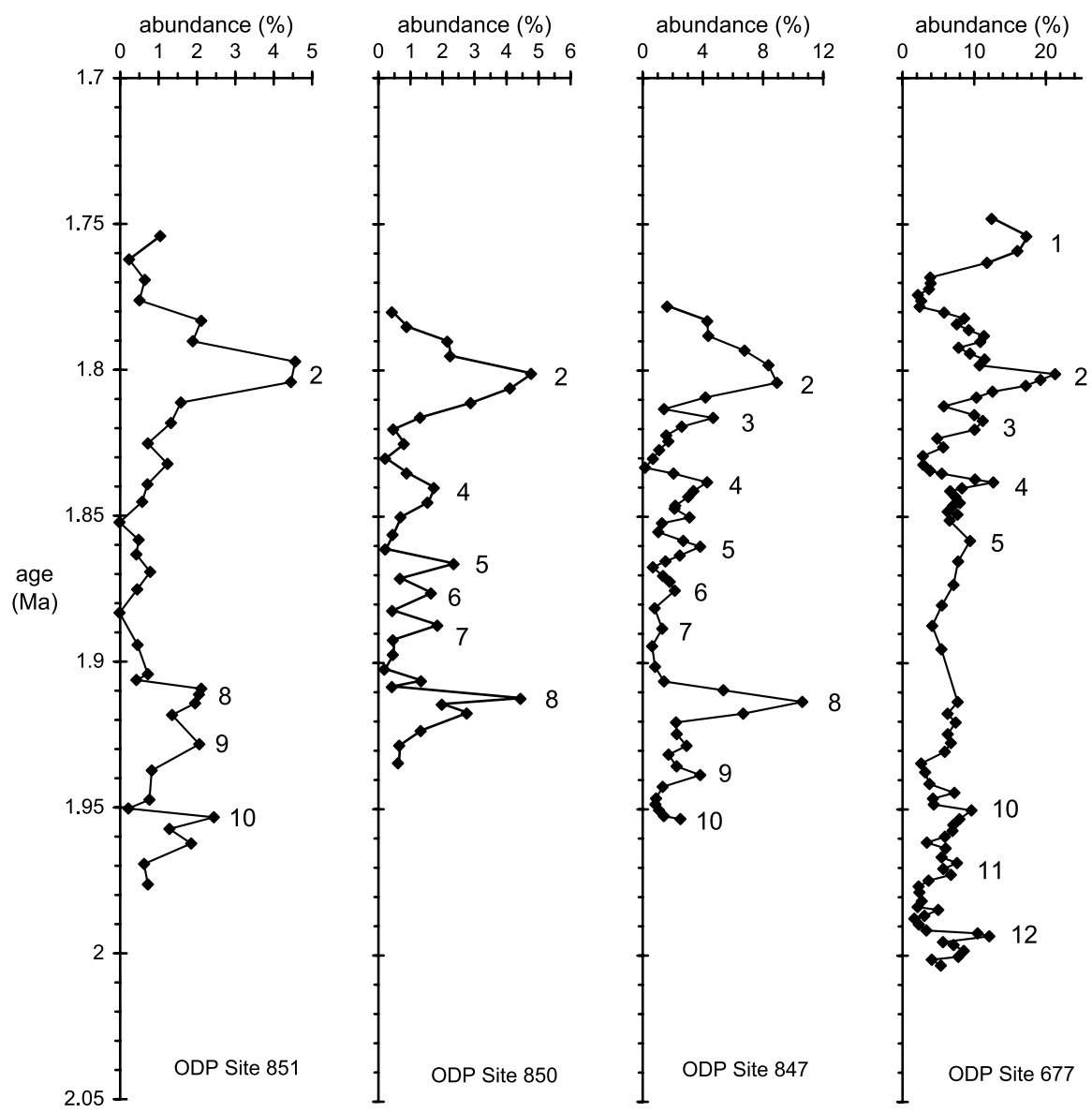

Fig. 2. Abundance events of Cycladophora davisiana throughout the Olduvai subchron of ODP Sites $677,847,850,851$ in the eastern equatorial Pacific (after Haslett \& Funnell, 1998).

(RN12), subdivided into two subzones, and NR8 and NR9 are replaced with a single zone (RN11), again with two subzonations. The varied use of zonal codes, where one scheme descends with time and the other ascends, is clearly unsatisfactory at present and may lead to confusion. It is suggested that efforts to harmonise the schemes should be made, but the present review is not a suitable vehicle for this task.

All ages given by Sanfilippo \& Nigrini (1998, fig. 2) for their zonation are palaeomagnetically derived, incorporated within the Geomagnetic Polarity Time Scale (GPTS) and, whilst this is justified in older Cenozoic sediments where orbitally tuned time-scales are lacking, ages for Late Neogene and Quaternary biodatums should now be (where possible) astronomically derived. They do provide tables for the conversion of ages from palaeomagnetic time-scales (e.g. Berggren et al., 1985a, b, 1995; Cande \& Kent, 1992, 1995) to an orbitally tuned time-scale (Shackleton et al., 1995) but, as mentioned above, interpolation of ages between magnetic reversals cannot incorporate sedimentation rate fluctuations, which may lead to considerable ageassignment errors. However, orbitally tuned time-scales are erected independently, unaffected by sediment accumulation rates and may establish age control points at $c .25 \mathrm{ka}$ intervals. Therefore, a biodatum inaccurately aged by palaeomagnetic interpolation will convert to an erroneous astronomically derived age.

\section{CYCLADOPHORA DAVISIANA ABUNDANCE EVENTS}

Cycladophora davisiana is generally a cold-water high-latitude species that evolved c. $2.5 \mathrm{Ma}$ (Motoyama, 1997) and whose relative abundance has been shown to vary synchronously through the Late Pliocene and Quaternary of high-latitude oceans (Hays et al., 1976; Morley, 1980, 1987; Morley \& Hays, 1979, 1983; Abelmann \& Gersonde, 1988; Björklund \& Ciesielski, 1994). The abundance variations of this species have been used as a means of correlating sedimentary sequences in a similar manner to $\delta^{18} \mathrm{O}$ stratigraphies (i.e. counting peaks and troughs in the continuous record). Indeed, some authors have dated $C$. davisiana abundance events using oxygen isotope stratigraphy, such as in the North Atlantic (Ciesielski \& Björklund, 1995) and in the subantarctic Atlantic Ocean (Brathauer et al., 2001). Abundance events have been variously coded by authors for ease of reference when cross-correlating different cores; either by letters (e.g. Hays et al., 1976), numbers (e.g. Haslett \& Funnell, 1998, Fig. 2), or alpha-numerically (e.g. Caulet, 1982, 1986). Although stratigraphies based on C. davisiana are widely used at mid- to high-latitude sites, Haslett \& Funnell (1998) demonstrated that the same method may also be applied with success to low-latitude sediments. These authors erect $C$. davisiana stratigraphies spanning the Olduvai subchron (Plio-Pleistocene) of ODP sites from the equatorial Indian and Pacific Ocean (sites 677, 709, 847, 850 and 851 ), as a means of 
independently evaluating high-resolution time-scales developed by other methods. The results are encouraging, with a high degree of consistency in the $C$. davisiana stratigraphies between all sites. In particular, Haslett \& Funnell (1998) recognize a major peak in C. davisiana abundance (Fig. 2) coincident with the Plio-Pleistocene boundary at 1.81 Ma (Hilgen, 1991). The percentage value of this peak varies from site to site, probably due to local palaeooceanographic factors (Haslett \& Funnell, 1998), but may represent a useful new biomarker for the Tertiary-Quaternary boundary, indicating a major intrusion of cool high-latitude water into the equatorial oceans at this time, perhaps associated with $\delta^{18} \mathrm{O}$ stage 64. Indeed, Ciesielski \& Björklund (1995) note that in the North Atlantic the initial major abundance peak of $C$. davisiana occurred near the stage 63/62 boundary. These results indicate that $C$. davisiana stratigraphy may have the potential for correlation not only in high-latitude regions, but also on intra- and inter-oceanic scales covering all latitudes. However, these promising indications require further research in the future. Furthermore, abundance variation in other species may also prove biostratigraphically useful. For example, Gupta (2002) demonstrates that temporal abundance variations in pyloniid radiolarians vary in a similar way to that of $C$. davisiana.

\section{CONCLUSIONS}

The range and precision of radiolarian applications in geological studies, including the Pliocene-Pleistocene, have developed since the work of William R. Riedel in the 1950s indicated their potential. This paper has focused on biostratigraphic applications. Much is now known concerning modes of evolution and extinction and specific dates when particular species appeared or became extinct. These biodatums have been dated primarily through palaeomagnetic means, interpolating time-scales between magnetic reversals. This has provided a reasonably accurate chronology, which, for most dating purposes, is adequate. However, such palaeomagnetic dating of biodatums cannot easily account for sediment accumulation rate variations between reversals. A more precise method of attributing dates is through the construction of astronomical time-scales, which involves much less interpolation, so reducing errors associated with sedimentation rates. Future refinement of radiolarian biodatums should logically employ such orbitally tuned time-scales. A number of biozonal schemes have been developed, based on radiolarian biodatums, which subdivide Pliocene-Pleistocene time and allow for sediment correlation on an inter-oceanic basis. Abundance variations of Cycladophora davisiana and some other taxa have been shown to fluctuate through time in response to environmental changes. These fluctuations have been shown to occur systematically on an inter-hemisphere and inter-oceanic scale allowing stratigraphies to be developed based on the identification of particular abundance events. This is particularly promising as it allows time-scales to be constructed in a similar manner and resolution to $\delta^{18} \mathrm{O}$ stratigraphies. However, this technique requires further confirmation of its potential from the analysis of deep-sea cores from widely distributed sites in the ocean. From this review, it is clear that radiolarian stratigraphy is currently not limited as suggested by Lowe \& Walker (1997) and their use is hampered only by preservation.

\section{ACKNOWLEDGEMENTS}

I am grateful to Kjell Björklund for his useful and insightful comments on the manuscript, and to an anonymous reviewer for further comments.

\section{Manuscript received 22 December 2002 Manuscript accepted 6 June 2003}

\section{REFERENCES}

Abelmann, A. \& Gersonde, R. 1988. Cycladophora davisiana stratigraphy in Plio-Plesitocene cores from the Antarctic Ocean (Atlantic sector). Micropaleontology, 34: 268-276.

Anderson, O.R. 1983. Radiolaria. Springer-Verlag, New York, 355pp.

Barron, J.A. 1985. Miocene to Holocene planktic diatoms. In: Bolli, H.M., Saunders, J.B. \& Perch-Nielsen, K. (Eds), Plankton Stratigraphy. Cambridge University Press, 763-809.

Berggren, W.A., Kent, D.V., Flynn, J.J. \& van Couvering, J.A. 1985a. Cenozoic geochronology. Geological Society of America Bulletin, 96: $1407-1418$.

Berggren, W.A., Kent, D.V. \& van Couvering, J.A. 1985b. The Neogene: Part 2. Neogene geochronology and chronostratigraphy. In: Snelling, N.J. (Ed.), The Chronology of the Geological Record. Geological Society, London, Memoirs, 10: 211-260.

Berggren, W.A., Kent, D.V., Swisher, C.C. III \& Aubry, M.-P. 1995. A revised Cenozoic geochronology and chronostratigraphy. SEPM Special Publication, 54: 129-212.

Björklund, K.R. 1976. Radiolaria from the Norwegian Sea, Leg 38 of the Deep Sea Drilling Project. Initial Reports of the Deep Sea Drilling Project, 38: 1101-1168.

Björklund, K.R. \& Ciesielski, P.F. 1994. Ecology, morphology, stratigraphy, and the paleoceanographic significance of Cycladophora davisiana davisiana. 1. ecology and morphology. Marine Micropaleontology, 24: 71-88.

Bolli, H.M. \& Saunders, J.B. 1985. Oligocene to Holocene low latitude planktic foraminifera. In: Bolli, H.M., Saunders, J.B. \& Perch-Nielsen, K. (Eds), Plankton Stratigraphy. Cambridge University Press, Cambridge, 155-262.

Brasier, M.D. 1980. Microfossils. Unwin Hyman, London, 193pp.

Brathauer, U., Abelmann, A., Gersonde, R., Niebler, H.S. \& Futterer, D.K. 2001. Calibration of Cycladophora davisiana events versus oxygen isotope stratigraphy in the subantarctic Atlantic Ocean - a stratigraphic tool for carbonate-poor Quaternary sediments. Marine Geology, 175: 167-181.

Cande, S.C. \& Kent, D.V. 1992. A new geomagnetic polarity time scale for the Late Cretaceous and Cenozoic. Journal of Geophysical Research, 97(B10): 13917-13952.

Cande, S.C. \& Kent, D.V. 1995. Revised calibration of the geomagnetic polarity time scale for the Late Cretaceous and Cenozoic. Journal of Geophysical Research, 100: 6093-6095.

Casey, R.E. 1993. Radiolaria. In: Lipps, J.H. (Ed.), Fossil Prokaryotes and Protists. Blackwell Scientific Publications, Boston, 249-284.

Caulet, J.P. 1982. Faunes de radiolaires et fluctuations climatiques dans les sédiments de l'Océan Indien austral: une nouvelle biozonation. Bulletin de la Société Géologique de France, 24: 555-562.

Caulet, J.P. 1986. A refined radiolarian biostratigraphy for the Pleistocene of the temperate Indian Ocean. Marine Micropaleontology, 11: 217-229.

Caulet, J.-P. \& Nigrini, C. 1988. The genus Pterocorys (Radiolaria) from the tropical late Neogene of the Indian and Pacific Oceans. Micropaleontology, 34: 217-235.

Caulet, J.-P., Nigrini, C. \& Schneider, D.A. 1993. High resolution Pliocene-Pleistocene radiolarian stratigraphy of the tropical Indian Ocean. Marine Micropaleontology, 22: 111-129.

Chen, P.H. 1975. Antarctic Radiolaria. Initial Reports of the Deep Sea Drilling Project, 28: 437-513.

Ciesielski, P.F. \& Björklund, K.R. 1995. Ecology, morphology, stratigraphy, and the paleoceanographic significance of Cycladophora davisiana davisiana. 2. stratigraphy in the North Atlantic (DSDP Site 609) and Labrador Sea (ODP Site 646B). Marine Micropaleontology, 25: $67-86$. 
De Wever, P., Azéma, J. \& Fourcade, E. 1994. Radiolaires et radiolarites: production primaire, diagenèse et paléogéographie. Bulletindes Centres de Recherches Exploration - Production Elf Aquitaine, 18: 315-379.

Foreman, H.P. 1975. Radiolaria from the north Pacific, Deep Sea Drilling Project, Leg 3. Initial Reports of the Deep Sea Drilling Project, 32: $579-676$.

Funnell, B.M., Haslett, S.K., Kennington, K., Swallow, J.E. \& Kersley, C.L. 1996. Strangeness of the equatorial Ocean during the Olduva magnetosubchron (1.95 to $1.79 \mathrm{Ma}$ ). In: Moguilevsky, A. \& Whatley, R. (Eds), Microfossils and Oceanic Environments. University of Wales, Aberystwyth Press, 93-109.

Goll, R.M. 1980. Pliocene-Pleistocene Radiolaria from the East Pacific Rise and the Galapagos spreading center, DSDP Leg 5. Initial Reports of the Deep Sea Drilling Project, 54: 425-454.

Goll, R.M. \& Björklund, K.R. 1980. The evolution of Eucoronis fridjofnanseni $\mathrm{n}$. sp. and its application to the Neogene biostratigraphy of the Norwegian-Greenland Sea. Micropaleontology, 24: 356-371.

Gupta, S.M. 2002. Pyloniid stratigraphy - a new tool to date tropical radiolarian ooze from the central tropical Indian Ocean. Marine Geology, 184: 85-93.

Haeckel, E. 1887. Report on the Radiolaria collected by H.M.S Challenger during the years 1873-1876. Report on the Scientific Results of the Voyage of the H.M.S. Challenger Zoology, 18: clxxxviii 1803pp. (140 plates).

Haslett, S.K. 1993. Polycystine Radiolaria: geological and environmental applications. Microscopy and Analysis, November: 14-16.

Haslett, S.K. 1994. Plio-Pleistocene radiolarian biostratigraphy and palaeoceanography of the mid-latitude North Atlantic (DSDP Site 609). Geological Magazine, 131: 57-66.

Haslett, S.K. 1995. Pleistocene radiolarian biostratigraphy and palaeoceanography of the North Atlantic. In: Scrutton, R.A., Stoker, M.S., Shimmield, G.B. \& Tudhope, A.W. (Eds), The Tectonics, Sedimentation and Palaeoceanography of the North Atlantic Region. Geological Society, London, Special Publications, 90: 217-225.

Haslett, S.K. 2002. Palaeoceanographic applications of planktonic Sarcodine Protozoa: Radiolaria and Foraminifera. In: Haslett, S.K (Ed.), Quaternary Environmental Micropalaeontology. Arnold, London, 139-162.

Haslett, S.K. \& Funnell, B.M. 1998. Low-latitude Plio-Pleistocene temporal abundance variations in the radiolarian Cycladophora davisiana Ehrenberg: stratigraphic and palaeoceanographic significance. In: Cramp, A., McLeod, C.J., Lee, S.V. \& Jones, E.J.W. (Eds), Geological Evolution of Ocean Basins: Results from the Ocean Drilling Program. Geological Society, London, Special Publications, 131: 83-89.

Haslett, S.K., Kennington, K., Funnell, B.M. \& Kersley, C.L. 1995. Pliocene-Pleistocene radiolarian and diatom biostratigraphy of ODP Hole 709C (equatorial Indian Ocean). Journal of Micropalaeontology, 14: $135-143$

Hays, J.D. 1965. Radiolaria and late Tertiary and Quaternary history of Antarctic Seas. In: Llano, G.A. (Ed.), Biology of Antarctic Seas II. American Geophysical Union (Antarctic Research Series), 5: 125-184.

Hays, J.D. 1967. Quaternary sediments of Antarctic Ocean. Progress in Oceanography, 4: 117-131.

Hays, J.D. 1970. Stratigraphy and evolutionary trends of Radiolaria in north Pacific deep sea sediments. In: Hays, J.D. (Ed.), Geological Investigations of the North Pacific. Geological Society of America Memoir, 126: 185-218.

Hays, J.D. \& Opdyke, N.D. 1967. Antarctic Radiolaria, magnetic reversals and climatic change. Science, 158: 1001-1011.

Hays, J.D., Imbrie, J. \& Shackleton, N.J. 1976. Variations in the Earth's Orbit: Pacemaker of the Ice Ages. Science, 194: 1121-1132.

Hedberg, H.D. (Ed.) 1976. International Stratigraphic Guide. International Subcommission on Stratigraphy, Wiley, New York, 283-295.

Hilgen, F.J. 1991. Astronomical calibration of Gauss to Matuyama sapropels in the Mediterranean and implication for the Geomagnetic Polarity Time Scale. Earth and Planetary Science Letters, 104: 226-244.
Johnson, D.A. \& Knoll, A.H. 1975. Absolute ages of Quaternary radiolarian datum levels in the equatorial Pacific. Quaternary Research, 5: 99-110.

Johnson, D.A. \& Nigrini, C.A. 1985. Synchronous and timetransgressive Neogene radiolarian datum levels in the equatorial Indian and Pacific Oceans. Marine Micropaleontology, 9: 489-523.

Johnson, D.A., Schneider, D.A., Nigrini, C.A., Caulet, J.P. \& Kent, D.V. 1989. Pliocene-Pleistocene radiolarian events and magnetostratigraphic calibrations for the tropical Indian Ocean. Marine Micropaleontology, 14: 33-66.

Kling, S.A. 1973. Radiolaria from the eastern North Pacific, Deep Sea Drilling Project Leg 18. Initial Reports of the Deep Sea Drilling Project, 18: 617-671

Kling, S.A. 1978. Radiolaria. In: Haq, B.U. \& Boersma, A. (Eds), Introduction to Marine Micropaleontology. Elsevier, New York, 203-244.

Lowe, J.J. \& Walker, M.J.C. 1997. Reconstructing Quaternary Environments (2nd edn). Longmans, Harlow, 446pp.

Martini, E. 1971. Standard Tertiary and Quaternary calcareous nannoplankton zonation. In: Farinacci, A. (Ed.), Proceedings II Planktonic Conference (Roma 1970), 2: 739-785.

Meyen, F.J.F. 1834. Über das Leuchten des Meeres und Beschreibung einiger Polypen und anderer niederer Tiere. Beiträge zur Zoologie, gesammelt auf einer Reise um die Erde. Nova acta Academie Caesareae Leopoldino Carolinae germanicae naturae curiosorum, Band 16 (=8), supplement 1, abh. 5: 125-216 (pls 27-36).

Moore, T.C. Jr 1995. Radiolarian stratigraphy, Leg 138. Proceedings of the Ocean Drilling Program, Scientific Results, 138: 191-232.

Moore, T.C. Jr, Shackleton, N.J. \& Pisias, N.G. 1993. Paleoceanography and the diachrony of radiolarian events in the eastern equatorial Pacific. Paleoceanography, 8: 567-586.

Morley, J.J. 1980. Analysis of the abundance variations of the subspecies Cycladophora davisiana. Marine Micropaleontology, 5: 205-214.

Morley, J.J. 1987. Comparison of the Pleistocene records of the radiolarian Cycladophora davisiana at high-latitude sites of the Deep Sea Drilling Project. Initial Reports of the Deep Sea Drilling Project, 94: 889-894.

Morley, J.J. \& Hays, J.D. 1979. Cycladophora davisiana: a stratigraphic tool for Pleistocene North Atlantic and interhemispheric correlation. Earth and Planetary Science Letters, 44: 383-389.

Morley, J.J. \& Hays, J.D. 1983. Oceanographic conditions associated with high abundances of the radiolarian Cycladophora davisiana. Earth and Planetary Science Letters, 66: 63-72.

Motoyama, I. 1997. Origin and evolution of Cycladophora davisiana Ehrenberg (Radiolaria) in DSDP Site 192, Northwest Pacific. Marine Micropaleontology, 30: 45-63.

Nigrini, C. 1971. Radiolarian zones in the Quaternary of the equatorial Pacific Ocean. In: Funnell, B.M. \& Riedel, W.R. (Eds), The Micropalaeontology of Oceans. Cambridge University Press, Cambridge, 443-461.

Nigrini, C. \& Caulet, J.P. 1988. The genus Anthocyrtidium (Radiolaria) from the tropical late Neogene of the Indian and Pacific Oceans. Micropaleontology, 34: 341-360.

Riedel, W.R. 1953. Mesozoic and Late Tertiary Radiolaria of Rotti. Journal of Paleontology, 27: 805-813.

Riedel, W.R. 1957. Radiolaria. A preliminary stratigraphy. Swedish Deep-Sea Expedition Reports, 6: 59-96.

Riedel, W.R. 1959. Oligocene and Lower Miocene Radiolaria in tropical Pacific sediments. Micropaleontology, 5: 285-302.

Riedel, W.R. 1967. Subclass Radiolaria. In: Harland, W.B. (Ed.), The Fossil Record. Geological Society, London, 291-298.

Riedel, W.R. \& Sanfilippo, A. 1978. Stratigraphy and evolution of tropical Cenozoic radiolarians. Micropaleontology, 24: 61-96.

Riedel, W.R. \& Sanfilippo, A. 1986. Morphological characters for a natural classification of Cenozoic Radiolaria, reflecting phylogenies. Marine Micropaleontology, 11: 151-170.

Ruddiman, W.F., Raymo, M. \& McIntyre, A. 1986. Matuyama 41,000 cycles: North Atlantic Ocean and northern hemisphere ice sheets. Earth and Planetary Science Letters, 80: 117-129.

Sanfilippo, A. \& Nigrini, C. 1998. Code numbers for Cenozoic low latitude radiolarian biostratigraphic zones and GPTS conversion tables. Marine Micropaleontology, 33: 109-156. 
Sanfilippo, A. \& Riedel, W.R. 1970. Post-Eocene 'closed' theoperid radiolarians. Micropaleontology, 16: 446-462.

Sanfilippo, A. \& Riedel, W.R. 1980. A revised generic and suprageneric classification of the artiscin (Radiolaria). Journal of Paleontology, 54: 1008-1011.

Sanfilippo, A. \& Riedel, W.R. 1982. Revision of the radiolarian genera Theocotyle, Theocotylissa and Thyrsocyrtis. Micropaleontology, 28 170-188.

Sanfilippo, A. \& Riedel, W.R. 1992. The origin and evolution of Pterocorythidae (Radiolaria): a Cenozoic phylogenetic study. Micropaleontology, 38: 1-36.

Sanfilippo, A., Westberg-Smith, M.J. \& Riedel, W.R. 1985. Cenozoic radiolaria. In: Bolli, H.M., Saunders, J.B. \& Perch-Nielsen, K. (Eds), Plankton Stratigraphy. Cambridge University Press, Cambridge, 631-712.

Shackleton, N.J. \& Hall, M.A. 1990. Pliocene oxygen isotope stratigraphy of Hole 709C. Proceedings of the Ocean Drilling Program Scientific Results, 115: 529-538.

Shackleton, N.J., Berger, A. \& Peltier, W.R. 1990. An alternative astronomical calibration of the lower Pleistocene time scale based on
ODP Site 677. Transactions of the Royal Society of Edinburgh: Earth Sciences, 81: 251-261.

Shackleton, N.J., Crowhurst, S., Hagelberg, T., Pisias, N.G. \& Schneider, D.A. 1995. A new Late Neogene time scale: application to ODP Leg 138 Sites. Proceedings of the Ocean Drilling Program, Scientific Results, 138: 73-101.

Spencer-Cervato, C., Lazarus, D.B., Beckmann, J.P. von Salis, Perch-Nielsen, K. \& Biolzi, M. 1993. New calibration of Neogene radiolarian events in the North Pacific. Marine Micropaleontology, 21: 261-293.

Wang, R.J. \& Abelmann, A. 1999. Pleistocene radiolarian biostratigraphy in the South China Sea. Science in China Series D - Earth Sciences, 42: 536-543.

Westberg, M.J. \& Riedel, W.R. 1978. Accuracy of radiolarian correlations in the Pacific Miocene. Micropaleontology, 24: 1-23.

Westberg-Smith, M.J., Tway, L.E. \& Riedel, W.R. 1986. Radiolarians from the North Atlantic Ocean, Deep Sea Drilling Project Leg 94. Initial Reports of the Deep Sea Drilling Project, 94: 763-777. 